\title{
Managing nutrient for both food security and environmental sustainability in China: an experiment for the world
}

\author{
Fusuo ZHANG (凶), Zhenling CUI, Weifeng ZHANG \\ Center for Resources, Environment and Food Security, China Agricultural University, Beijing 100193, China
}

\begin{abstract}
The challenges of how to simultaneously ensure global food security, improve nitrogen use efficiency (NUE) and protect the environment have received increasing attention. However, the dominant agricultural paradigm still considers high yield and reducing environmental impacts to be in conflict with one another. Here we examine a Three-Step-Strategy of past 20 years to produce more with less in China, showing that tremendous progress has been made to reduce $\mathrm{N}$ fertilizer input without sacrificing crop yield. The first step is to use technology for in-season root-zone nutrient management to significantly increase NUE. The second is to use technology for integrated nutrient management to increase both yield and NUE by $15 \%-20 \%$. The third step is to use technology for integrated soil-crop system management to increase yield and NUE by $30 \%-50 \%$ simultaneously. These advances can thus be considered an effective agricultural paradigm to ensure food security, while increasing NUE and improving environmental quality.
\end{abstract}

Keywords integrated nutrient management, integrated soil-crop system management, environmental protection, food security, resource use efficiency

\section{Introduction}

Increasing population and consumption are putting unprecedented pressure on agricultural and natural resources [1-3]. It has been projected that chemical nitrogen $(\mathrm{N})$ fertilizer consumption would increase by $142 \%-169 \%$ to support a $100 \%-110 \%$ increase in global food crop yields from 2005 to 2050 [4,5]. Agricultural intensification must also address tremendous environmental concerns, such as climate change, degradation of land

Received March 14, 2014; accepted March 31, 2014

Correspondence: zhangfs@cau.edu.cn and freshwater, and biodiversity loss [1,3,6,7]. Agriculture, including fertilizer production, directly contributes $10 \%-$ $12 \%$ of global greenhouse gas (GHG) emissions, and this figure rises to $30 \%$ or more when land conversion and emissions beyond the farm gate are included [8]. These intertwined challenges necessitate a new imperative for global agriculture, where higher grain yields are produced with more efficient use of $\mathrm{N}$ fertilizer and a reduction in both reactive $\mathrm{N}$ losses and GHG emissions.

The challenges of producing more with less is particularly daunting in China, the world's most populous country and largest user of $\mathrm{N}$ fertilizer for crop production with 0.1 to $0.3 \mathrm{hm}^{2}$ of arable land per person [9]. On one hand, crop production must reach $580 \mathrm{Mt}$ (an increase of over $40 \%$ ), and yield needs to increase by $2 \%$ annually to meet the demand for grain and feed by 2030 [10]. On the other hand, the average productivity of cereal crops worldwide has already reached a higher level with the introduction and rapid adoption of Green-revolution technologies during the 1960 s to 1990 s. However, the rate of grain in cereal yields has slowed markedly in the past 10 to 20 years, even though $\mathrm{N}$ and phosphorus (P) have continued to increase. That large increase in inputs without a correspondingly large increase in yields further decreased the already-low ratio of grain harvested to fertilizer applied in China, and in consequence has driven environmental pollution problems, such as eutrophication [11], greenhouse gas emissions [12], and soil acidification [6]. These problems have become increasingly severe in rapidly developing countries, and their impacts are significant on a global scale.

In this article, we will introduce China's current agricultural production with a focus on managing nutrient, and examining problems and challenges associated with the current intensive agricultural system. We will summarize and thoroughly discuss the new approach: a ThreeStep-Strategy, developed over the past 20 years to enhance agricultural productivity and meet future food demand while improving resource use efficiency and reducing the environmental footprint. 


\section{Current crop production: an intensive system with high input, high output, and a large environmental footprint}

The Green Revolution helped to create the world's 'Miracle in China' with $9 \%$ of the world's arable land feeding $21 \%$ of the world population. Over the past 52 years (1961-2012), cereal grain yields have increased 3.8fold from 1.2 to $5.8 \mathrm{t} \cdot \mathrm{hm}^{-2}$, while total grain production has increased 3.9-fold from 110 to $543 \mathrm{Mt}$ [13]. However, this 3.8-fold increase in agricultural food production in China can be partly attributed to a 50 -fold increase in chemical fertilizers [5]. As a consequence, over the past 10 years (2003-2012), 39\% of the global increase in chemical fertilizer consumption ( $\sim 27 \mathrm{Mt}$ ) was from China, including 8.3 Mt fertilizer $\mathrm{N}$ ( $41 \%$ of the global increase), $1.8 \mathrm{Mt}$ fertilizer $\mathrm{P}$ (33\% of the global increase) and $0.6 \mathrm{Mt}$ fertilizer potassium (K) (32\% of the global increase) [5]. In 2013, total N, P, and K fertilizer consumption (i.e., units of $\mathrm{N}, \mathrm{P}_{2} \mathrm{O}_{5}$, and $\mathrm{K}_{2} \mathrm{O}$ ) amounted to 51.5 Mt [5].

Although $\mathrm{N}$ and $\mathrm{P}$ consumption have continued to increase in the past 10 to 20 years, the rate of gain in cereal yields has slowed markedly, even stagnated. From 1998 to 2012 , grain yields increased by only $18 \%$, while the consumption of chemical fertilizers increased by nearly $43 \%$ [5,6]. For wheat (Triticum aestivum L.), maize (Zea mays L.) and rice (Oryza sativa L.) the average $\mathrm{N}$ rate increased to 200 to $300 \mathrm{~kg} \cdot \mathrm{hm}^{-2}$ [14,15], which was above the economically optimal $\mathrm{N}$ rate of 120 to $180 \mathrm{~kg} \cdot \mathrm{hm}^{-2}$ based on region-wide studies [16-21]. Inevitably, the significant increases in fertilizer application and a lack of proportional yield response over the past two decades have decreased nutrient use efficiency and increased $\mathrm{N}$ losses to the environment. For example, recovery efficiency for $\mathrm{N}$ $\left(\mathrm{RE}_{\mathrm{N}}\right.$, calculated as the percentage of $\mathrm{N}$ fertilizer recovered in the aboveground plant parts at maturity) in China's cereal grain production decreased from $35 \%$ in the 1980 s [22] to $28 \%$ at the beginning of 2000 s $(28 \%$ for rice and wheat, and $26 \%$ for maize) [23]. By comparison, the average $\mathrm{RE}_{\mathrm{N}}$ value for rain-fed crops, irrigated corn in North American, and global crop production were 36\%, $57 \%$, and $33 \%$, respectively [24,25].

Environmental degradation associated with nutrient underutilization, primarily from agricultural systems, has been well documented in China. Approximately $60 \%$ of inland lakes in China suffered from eutrophication, with $57 \%$ of $\mathrm{N}$ and $67 \%$ of $\mathrm{P}$ entering waters derived from agriculture [26]. In the major crop production regions of China, soil $\mathrm{pH}$ decreased by 0.5 units from the 1980 s to the 2000 s, attributed mainly to excessive application of $\mathrm{N}$ fertilizers [6]. Atmospheric $\mathrm{N}$ deposition increased significantly. On the North China Plain, total wet and dry deposition of $\mathrm{N}$ averaged 80 to $90 \mathrm{~kg} \cdot \mathrm{hm}^{-2} \cdot \mathrm{yr}^{-1}$ in the 2000s [27-30], which was approximately 5 -fold greater than at Rothamsted, Harpenden, UK [31] or in central New
York state in the USA [32]. In addition, life-cycle analyses have shown that GHG emissions from China's $\mathrm{N}$ fertilizer chain amounted to $452 \mathrm{Mt} \mathrm{CO}_{2}$-equivalent per year, which accounts for $7 \%$ of the total GHG emissions from the entire national economy [33].

\section{The Three-Step-Strategy for nutrient management to produce more with less in China}

Improving the productivity and sustainability of agricultural systems must follow new trajectories, if they are to address the challenge of greatly increasing yields to meet growing demand for food without further compromising environmental integrity. Several conceptual frameworks have been proposed to guide efforts that could produce higher yields with reduced input or environmental costs. These frameworks include ecological intensification [34], an evergreen revolution [35], and eco-efficient agriculture [36,37], and they share a view of cropping systems as ecosystems that should be designed to maximize the use of fixed resources (land, light, favorable growing conditions) and optimize the use of agricultural inputs (particularly $\mathrm{N}$ and $\mathrm{P}$ ) to produce high grain yields. While there is agreement regarding the need for such improvements, there are only a few examples of how they can be developed and adopted on a large scale, and across hundreds of millions of farmers' fields.

Scientists from China Agricultural University have collaborated with partners from over 30 research units including universities and academies of agricultural sciences to increase yields and improve NUE at the same time based on more than 20 years of studies. For managing nutrient to produce more with less, there were three steps to achieve the needs of increasing food production with greater protection of the environment (Fig. 1). In the firststep, an in-season root-zone nutrient management (IRNM) for fine-tuning nutrient management based on soil and plant testing has been introduced and developed to optimize nutrient supplies and improve NUE. This approach has been extremely successful in terms of maximizing NUE. However, attempts to increase substantial and consistent yield have met with limited success. In the second step, the integrated nutrient management (INM) has been developed, with nutrient root-zone/ rhizosphere management to improve NUE and crop genotypes that are being bred, together with improved agronomic management practices to close the yield gap. The target of this step is to increase both yield and NUE by $15 \%-20 \%$ at the same time, compared to current farmers' practice. In the third step, an integrated soil-crop system management (ISSM) has been developed with improving soil quality, INM and increasing yield greatly based on innovation of agronomic practices. The goal of this step is to increase crop yield and NUE by $30 \%-50 \%$ at the same 


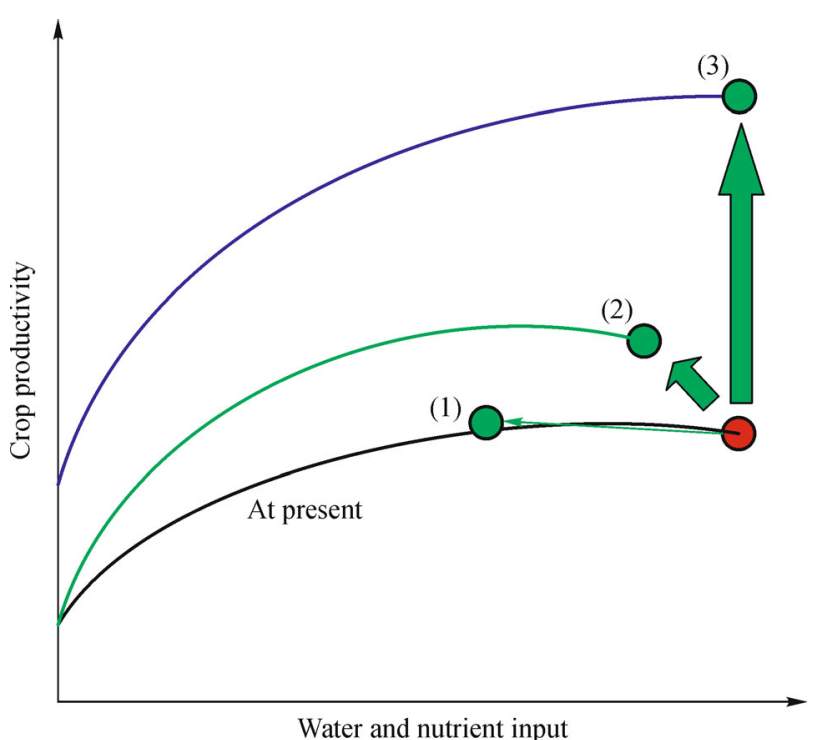

Fig. 1 Conceptual framework for nutrient management development with Three-Step Strategy to synchronously increase crop productivity, improve resource use efficiency, and protect the environment. (1)Reducing input without sacrificing yield by inseason root-zone nutrient management; (2) increasing yield and NUE significantly by $15 \%-20 \%$ by integrated nutrient management; (3) maximizing the productivity and sustainability at the same time to increase yield and NUE by $30 \%-50 \%$ by integrated soil-crop system management. The red dot means current farming practice.

time to achieve food security in 2030, when China reaches its peak population.

\subsection{The First-Step-Strategy: IRNM to improve NUE}

Current nutrient management often treats a series of complex biogeochemical $\mathrm{N}$ cycle processes in the agroecosystem as a 'black box', such as yield response curves, soil and plant tests, and more recently the application of remote sensing technologies [38-40]. These agronomic approaches have largely been successful in terms of maximizing crop yields and economic returns, especially in nutrient deficit regions over the last half century [38]. However, attempts to reduce $\mathrm{N}$ losses to the environment have achieved limited success. Despite more than 30 years of concentrated effort, mass balances indicated annual $\mathrm{N}$ and $\mathrm{P}$ inputs consistently exceed harvested exports by $40 \%$ to $100 \%$ or more resulting in substantial losses of these nutrients to the environment in China [41].

Since the 1990s, an in-season root-zone N management strategy has been developed in China (IRNM, Fig. 2) $[16,19,20,42]$. According to this strategy, the total amount of $\mathrm{N}$ fertilizer is divided into two or three applications over the course of the growing season, with the optimum $\mathrm{N}$ fertilizer rate for each application being determined from soil nitrate- $\mathrm{N}$ tests in the root-zone and a target $\mathrm{N}$ value for the corresponding growth period of the crop. The two or three soil nitrate tests can be used to estimate root-zone soil $\mathrm{N}$ supply to match seasonal crop $\mathrm{N}$ demand and for finetuning of $\mathrm{N}$ rate and timing of $\mathrm{N}$ applications.

In practice, compared with farming $\mathrm{N}$ practice, the IRNM strategy (wheat, $n=121$; maize, $n=148$ ) reduced $\mathrm{N}$ fertilizer by $40 \%-60 \%$ for wheat and maize, and simultaneously increased grain yield by $4 \%-5 \%$. As expected, the $\mathrm{RE}_{\mathrm{N}}$ for IRNM increased by $94 \%-146 \%$, $\mathrm{Nr}$ losses were reduced by $45 \%-80 \%$, compared to farming $\mathrm{N}$ practice (Fig. 2). Clearly, the optimum $\mathrm{N}$ fertilizer rate using IRNM was close to being achieved, with high yields sustained and increased profits, while minimizing the potential environmental impacts of $\mathrm{N}$ fertilization. This superiority of IRNM strategy can be attributed to two major factors: (1) achievement of synchronization between $\mathrm{N}$ supply and crop demand; (2) addressing site-specific N management $[19,20]$.

Unlike $\mathrm{N}$, management of fertilizer $\mathrm{P}$ and $\mathrm{K}$ focuses on maintenance of adequate soil available $\mathrm{P}$ and $\mathrm{K}$ levels in the root zone to ensure that neither P nor K supply limits crop growth or becomes excessive due to over-fertilization. In China, fertilizer $\mathrm{P}$ or $\mathrm{K}$ rates are recommended on the basis of regular monitoring of soil nutrient supplies and nutrient holding capacities $[43,44]$. In soils with low $\mathrm{P}$ status and/or high fixation capacity, capital investment is required to build up soil nutrients until the system becomes profitable and sustainable. On soils with moderate $\mathrm{P}$ and $\mathrm{K}$ levels and little fixation, management must focus on balancing inputs and outputs at field and farm scales to maximize profit, avoid excessive accumulation and minimize risk of $\mathrm{P}$ losses [24]. Therefore, managing nutrients to achieve synchrony between nutrient supply and crop demand is crucial to increase NUE while maintaining agricultural productivity and improving technical operability.

3.2 The Second-Step-Strategy: INM to increase grain yield and NUE

A primary requirement for the future is to produce higher yields with inputs that do not lead to environmental problems either on- or off-site. To this end, INM was developed to maximize NUE based on root-zone/rhizosphere management, and close grain yield gap based on improved crop management. The INM included four management components: (1) optimizing nutrient inputs by taking all possible nutrient sources into consideration; (2) matching nutrient supply in the root-zone with crop requirements spatially and temporally; (3) reducing nutrient losses in intensively managed cropping systems; (4) taking all possible yield-increasing measures into consideration [45].

Recent literatures on improving the $\mathrm{RE}_{\mathrm{N}}$ in crop production have emphasized the need for greater synchrony between crop $\mathrm{N}$ demand and $\mathrm{N}$ supply from all sources throughout the growing season, such as from air 


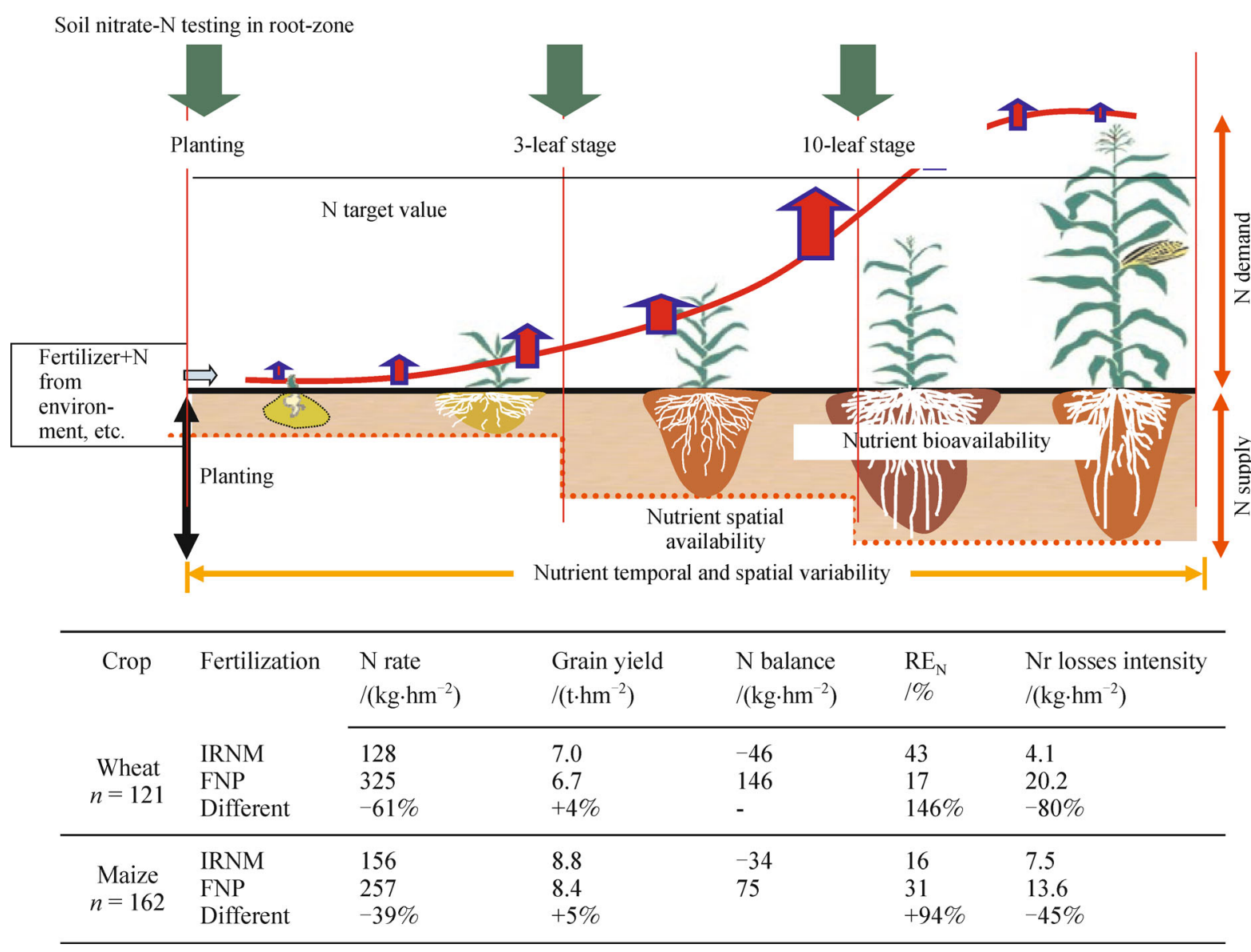

Fig. 2 Schematic of in-season root-zone N management for maize production in China, and performance of IRNM for wheat and maize on the North China Plain. Mean $\mathrm{N}$ rate, grain yield, $\mathrm{N}$ balance, recovery $\mathrm{N}$ efficiency $\left(\mathrm{RE}_{\mathrm{N}}\right)$ and $\mathrm{Nr}$ losses intensity. Modified from Cui et al. $[19,20]$

and irrigation water, as well as the residual $\mathrm{N}$ in the rootzone $[1,46,47]$. For example, on the North China Plain, as well as in the Taihu Lake region in eastern China, atmospheric deposition and irrigation added as much as 89 and $106 \mathrm{~kg} \mathrm{~N} \cdot \mathrm{hm}^{-2} \cdot \mathrm{yr}^{-1}$ to the soil in the $2000 \mathrm{~s}$, respectively, compared to roughly $30 \mathrm{~kg} \cdot \mathrm{hm}^{-2} \cdot \mathrm{yr}^{-1}$ in the 1980s [48]. Nitrate-N in the top $90 \mathrm{~cm}$ soil profile amounts to about $200 \mathrm{~kg} \cdot \mathrm{hm}^{-2}$ in intensive wheat-maize systems $[49,50]$, and 1173 and $613 \mathrm{~kg} \cdot \mathrm{hm}^{-2}$ in greenhouse vegetable and orchard production systems in northern China, respectively [51,52]. As a net result of soil $\mathrm{N}$ transformation, transport, fertilizer applications, and environmental $\mathrm{N}$ supply, soil $\mathrm{N}$ supply significantly contributes to the crop $\mathrm{N}$ requirement. Therefore, INM leads to an improvement in soil $\mathrm{N}$ supply to the root-zone within a reasonable range that matches the required quantity and is synchronized in terms of time and crop growth, and coupled in space to the $\mathrm{N}$ supply and crop $\mathrm{N}$ requirements.

On average from 2003 to 2010 across 5147 experiment at 158 locations, INM reduced $\mathrm{N}$ fertilizer inputs by $24 \%$, increased yields by $12 \%$, increased NUE by $40 \%$, and increased net farm income by US\$132 per $\mathrm{hm}^{2}$ [45]. Three factors contributed to this improvement: (1) elite cultivars capable of producing well at high planting densities and also with high yield potential; (2) integrated nutrient and water management, especially $\mathrm{N}$ management; (3) better crop management including tillage, sowing, density and pest management (Fig. 3).

3.3 The Third-Step-Strategy: ISSM to produce more with less

In the longer-term future, cereal crop yield and NUE should be increased $30 \%$ to $50 \%$ at the same time, compared to current farmer's practice, to ensure food security and minimize environmental degradation. In this step, the ISSM developed consisted of four principal aspects: (1) improving soil quality by recycling organic resources; (2) enhancing NUE accounting for various nutrient sources and matching nutrient supply with the dynamics of crop needs; (3) reducing the gap between potential yield and actual yield using superior varieties and improved cultivation; (4) reducing $\mathrm{N}$ loss by cutting $\mathrm{N}$ loss pathways. 


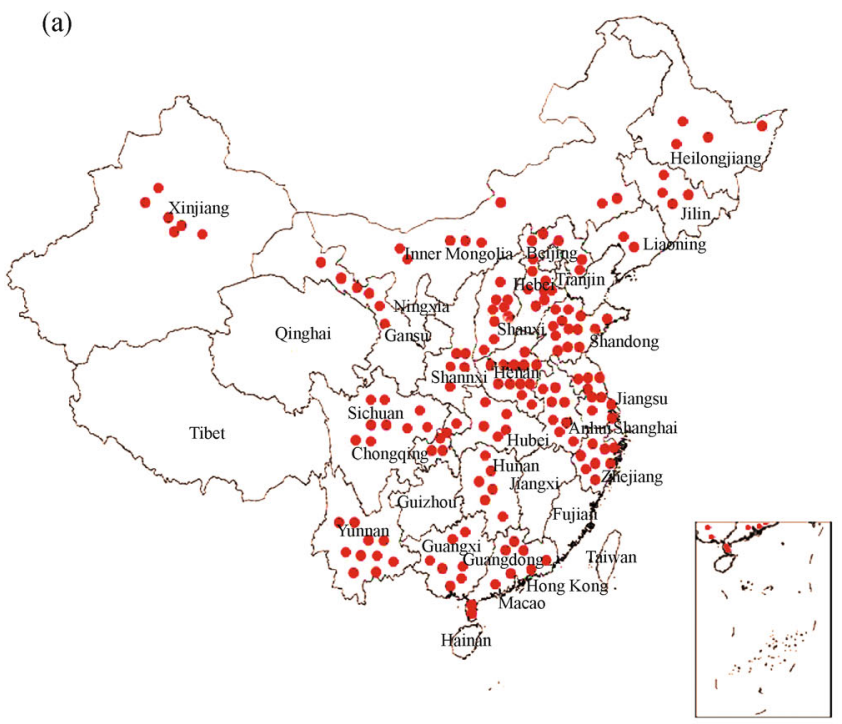

(b)

\begin{tabular}{lcccc}
\hline Crops & $n$ & $\begin{array}{c}\Delta \text { yields } \\
1 \%\end{array}$ & $\begin{array}{c}\Delta \text { N rate } \\
1 \%\end{array}$ & $\begin{array}{c}\Delta \text { net income } \\
/ \$ \mathrm{hm}^{-2}\end{array}$ \\
\hline Wheat & 558 & 10 & 29 & 92 \\
Maize & 2100 & 16 & 25 & 111 \\
Rice & 1861 & 8 & 21 & 99 \\
Vegetable & 310 & 6 & 39 & 397 \\
Fruit & 57 & 13 & 28 & 775 \\
Rape & 239 & 12 & 8 & 196 \\
Cotton & 22 & 7 & 36 & 164 \\
Average & & 12 & 24 & 132 \\
\hline
\end{tabular}

Fig. 3 Performance of INM in China. (a) 158 locations (red dots) for INM dissemination in China; (b) increased yield, reduced N fertilizer rate, and increased net income of INM for different crops including wheat, maize, rice, vegetable, fruit, rape, and cotton, compared farmers' practice. $\Delta$ yield, $\mathrm{N}$ fertilizer, and net income mean the different yields, $\mathrm{N}$ fertilizer rate, and net income between INM and farmer's practice. Modified from Zhang et al. [45]

As average farm yields approach $80 \%$ to $90 \%$ of the yield potential (the yield of a crop cultivar when grown in environments to which it is adapted, with nutrients and water non-limiting and pests and diseases effectively controlled), it becomes more difficult for farmers to sustain yield increases because further gains require the elimination of small imperfections in the integrated management of soil, crops, water, nutrients and pests [53]. The further yield improvement in the long term future should increase yield potential; despite the substantial input-driven increase in yields in past decades and despite substantial yield gaps persist in most extensive agricultural regions [54]. Genetic and breeding research leading to the development of more productive/better protected/more efficient cultivars will continue to contribute to increasing yields, and possibly increase yield ceilings. Meanwhile, the development, application and adaptation of appropriate cropping systems also can be optimized to make use of solar radiation and periods with favorable temperatures to the maximum possible extent, and contribute substantially to increasing yields and decreasing environmental degradation. For example, the yield potential of maize in Beijing City can be increased to $14.1 \mathrm{t} \cdot \mathrm{hm}^{-2}$ with elite cultivars, optimal sowing date and high density, compared to 8.9 $\mathrm{t} \cdot \mathrm{hm}^{-2}$ under current practice.

Crop productivity is strongly dependent on soil quality. As an elusive concept, assessing soil quality is a major challenge because it varies spatially and temporally, and is affected by management and the use of soil resource. Soil quality that can easily achieve high yield and high efficiency at the same time should be: (1) conducive to crop root growth and development; (2) conducive to the timely supply and high efficiency use of water and nutrients; (3) of good buffering capacity and system stability. A key tenet of ISSM is the importance of building up the soil organic carbon pool in Chinese croplands by appropriate, sustainable management strategies, such as returning large quantities of biomass to the soil and/or decreasing losses of soil organic carbon through erosion, mineralization and leaching. Adopting and sustaining the use of such practices is necessary to restore soil quality and achieve the higher crop yields needed to meet China's food security challenges in the future. Additional improvements in soil quality can occur when the benefits of carbon sequestration are coupled with increases in crop yields from adoption of cultivation practices that reduce yield losses from abiotic and biotic stresses, such as returning straw back to the soil, increasing applications of organic manures and using reduced tillage.

In practice, a model-driven ISSM approach were used to design new crop cultivation system for improving yields, and INM for improving fertilizer usage [9]. Crop system was designed by optimal combinations of plant variety, planting dates, and crop density to ensure maximum benefits from solar radiation and from favorable temperatures, and manage root-zone nutrient supply with reasonable level to ensure non-limiting $\mathrm{N}$ supply with minimum losses to the environment, to match the total quantity required for the model-designed maize system in dose, space and time. As a result, mean maize yields of 13.0 $\mathrm{t} \cdot \mathrm{hm}^{-2}$ on 66 on-farm experimental plots were achieved nearly twice the yield of current farmers' practices with no increase in $\mathrm{N}$ fertilizer use. The NUE was also increased from $26 \mathrm{~kg}$ of grain per $\mathrm{kg}$ of $\mathrm{N}$ with farmer's practice to 
$57 \mathrm{~kg}$ of grain per $\mathrm{kg}$ of $\mathrm{N}$ for ISSM approach (Fig. 4). In other on-farm studies $(n=18)$, this ISSM increased yield $\left(14.8 \mathrm{t} \cdot \mathrm{hm}^{-2}\right)$ by $70 \%$, compared to farming $\mathrm{N}$ practice, which is only $38 \%$ more $\mathrm{N}$ fertilizer input, and, $\mathrm{N}_{2} \mathrm{O}$ emission intensity and the GHG intensity of the ISSM system were reduced by $12 \%$ and $19 \%$, respectively.

\section{General discussion: areas of future research and policy}

Results of these field experiments showed 30\%-50\% increase of NUE with target of first-step having been achieved in practice, and the 15\%-20\% increase of both yield and NUE with target of second-step having been partly achieved in practice, and 30\%-50\% increase of yield and NUE has only been achieved so far in the maize belt under experimental conditions. We believe that the principles are applicable to other regions, and similar improvements may be achieved if we invest in agronomic research that incorporates an ecosystem perspective, if the effort to modify and adapt intensive agricultural systems is pursued across disciplinary boundaries, and if an effective and multi-channel agricultural technology transfer and extension system is established and fully functional.

Different agricultural developments require different technology and policy. Generally, policy supporting reduced nutrient supplies with a nutrient balance surplus (as in China) or added nutrient supplies with nutrient balance deficit (as in sub-Saharan Africa). On a regional scale, higher crop yields are likely to be achieved through a combination of increased $\mathrm{N}$ application in regions with a low $\mathrm{N}$ input, and improved $\mathrm{NUE}$ in regions where $\mathrm{N}$ fertilizer use is already high. Countries with $\mathrm{N}$ balanced may also be able to concurrently increase grain yield and NUE with increased yield potential by employing new ISSM technology (as in the maize belt in USA), and closing the yield gap with INM to reduce $\mathrm{N}$ fertilizer rates without yield loss by improved cultivars, region-specific farming practices, slow-release $\mathrm{N}$ fertilizer, drip irrigation, crop rotation, bio-inoculants and similar approaches.

In China, the current difficulty in implementing ISSM is a consequence of a lack of efficient channels to transfer technologies to Chinese farms. Small-scale farming with high variability between fields and a poor infrastructure has reduced the efficiency of current ISSM practices [21]. Additionally, the low profits in the agricultural sector, an increasing number of educated young farmers leaving the industry means farm work is left to the older and lesseducated generation $[55,56]$. Thus, it is difficult to train and motivate farmers to use new techniques, which seriously limits sustainable nutrient management and agricultural development in China.

Wide adoption of the ISSM approach across the country will rely heavily on effective and multi-channel agricultural technology transfer and extension, engaging both public and private sectors $[57,58]$. This may be achieved through a combination of three pathways: (1) working directly with and transferring knowledge to farmers through organized farmer cooperatives, which are becoming more common; (2) enterprise-based approaches embodying relevant scientific results into commercial products, which would require close collaboration between the research community and business entities such as

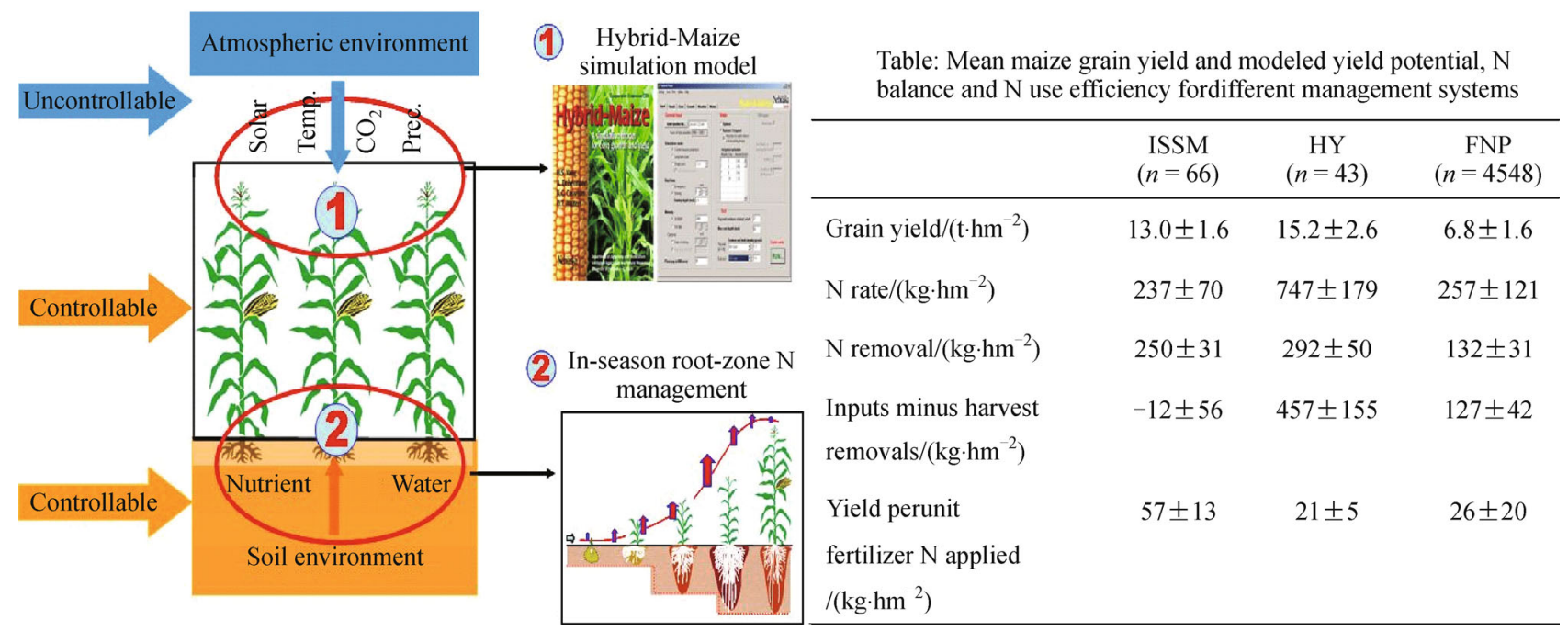

Fig. 4 Conceptual framework for the ISSM approach. Using the Hybrid-Maize model [29] (1), we selected the most appropriate combination of planting date, crop maturity, and crop variety to optimize capture of radiation and favorable growing conditions at a given site. Using an IRNM strategy [32,33] (2), we managed total $\mathrm{N}$ supply to match high-yielding crop $\mathrm{N}$ requirements in time, space, and quantity. The Table includes mean maize grain yield, $\mathrm{N}$ balance (fertilizer inputs-harvest outputs), and $\mathrm{N}$ applied per unit of grain produced for different management systems. Modified from Chen et al. (2011) [9] 

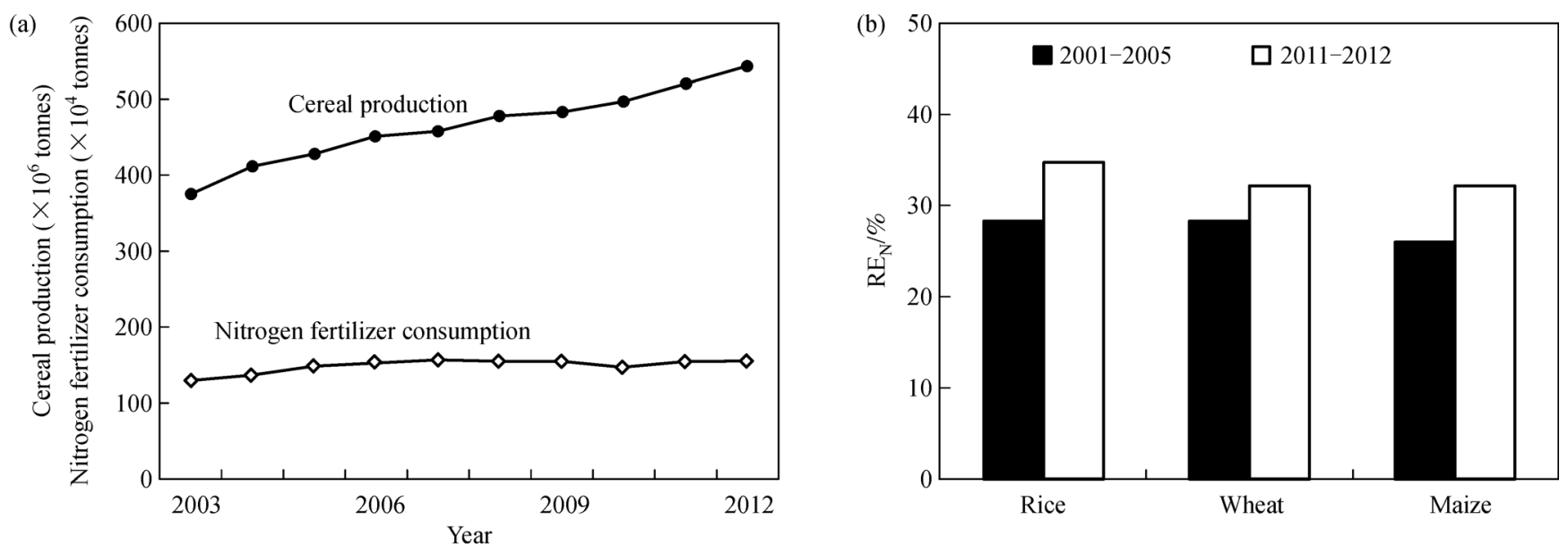

Fig. 5 The trends in (a) grain production and chemical nitrogen fertilizer inputs for cereal production in China from 2003 to 2012, and (b) the difference of $\mathrm{RE}_{\mathrm{N}}$ between 2001-2005 and 2011-2012 for rice, wheat and maize. Source data: cereal production comes from FAO; nitrogen fertilizer consumption comes from China's report of development and research on fertilizer; NUE comes from the Ministry of Agriculture of China

fertilizer companies; (3) government-sponsored approaches with vastly improved agricultural extension systems. We believe that by engaging agricultural economists, policy experts, extension specialists and, most crucially, farmers themselves, effective programs can be developed with working solutions and guidelines to address the specific needs of various regions for the ultimate goal of food security and environmental sustainability [59].

There are signs of positive changes in cereal production of China. For example, cereal production increased by $45 \%$ from $374 \mathrm{Mt}$ in 2003 to $543 \mathrm{Mt}$ in 2012 with $15 \%$ increased $\mathrm{N}$ application rate. As a result, $\mathrm{RE}_{\mathrm{N}}$ increased from $28 \%$ to $33 \%$ (Fig. 5). Also, a series of national programs have been initiated (such as soil testing and fertilizer recommendations) for scientists to collaborate across disciplines and to conduct costly but effective demonstration trials on-the-farm in a wide range of soil and crop systems. For example, scientists from China Agricultural University have joined with researchers from dozens of institutions to develop and field-test the ISSM approach [60]. The success of ISSM suggested that productivity could be improved while stabilizing (or even reducing) chemical fertilizer inputs.

Globally, environmental and economic constraints (e.g., rising cost of fossil fuels) dictate that future food supply must be attained through improved production efficiency rather than further increasing resource inputs, especially $\mathrm{N}$ and $\mathrm{P}[1,34,61]$. Producing sufficient food to feed an everincreasing and more prosperous population, and at the same time minimizing the ecological footprint, is difficult. The methods that China uses to attain these goals will have implications worldwide. A food self-sufficient China would have a tremendous positive global effect. Additionally, China's developmental path for agriculture will provide valuable information for the sustainable development in other nations, particularly in Asia and Africa.

Acknowledgements We thank the National Basic Research Program of China (2009CB118606), the Special Fund for Agro-Scientific Research on the Public Interest (201103003) and the Innovative Group Grant of the National Science Foundation of China (31121062) for financial support.

Compliance with ethics guidelines Fusuo Zhang, Zhenling Cui and Weifeng Zhang declare that they have no conflict of interest or financial conflicts to disclose.

This article does not contain any studies with human or animal subjects performed by the any of the authors.

\section{References}

1. Tilman D, Cassman K G, Matson P A, Naylor R, Polasky S. Agricultural sustainability and intensive production practices. Nature, 2002, 418(6898): 671-677

2. Foley J A, Ramankutty N, Brauman K A, Cassidy E S, Gerber J S, Johnston M, Mueller N D, O'Connell C, Ray D K, West P C, Balzer C, Bennett E M, Carpenter S R, Hill J, Monfreda C, Polasky S, Rockström J, Sheehan J, Siebert S, Tilman D, Zaks D P. Solutions for a cultivated planet. Nature, 2011, 478(7369): 337-342

3. Burney J A, Davis S J, Lobell D B. Greenhouse gas mitigation by agricultural intensification. Proceedings of the National Academy of Sciences of the United States of America, 2010, 107(26): 1205212057

4. Tilman D, Balzer C, Hill J, Befort B L. Global food demand and the sustainable intensification of agriculture. Proceedings of the National Academy of Sciences of the United States of America, 2011, 108(50): 20260-20264

5. IFA. 2013. IFADATA-International Fertilizer Industry Association. www.fertilizer.org/ifa/HomePage/STATISTICS, 2013-11-04

6. Guo J H, Liu X J, Zhang Y, Shen J L, Han W X, Zhang W F, 
Christie P, Goulding K W T, Vitousek P M, Zhang F S. Significant acidification in major Chinese croplands. Science, 2010, 327(5968): $1008-1010$

7. Liu X J, Zhang Y, Han W X, Tang A H, Shen J L, Cui Z L, Vitousek P, Erisman J W, Goulding K, Christie P, Fangmeier A, Zhang F S. Enhanced nitrogen deposition over China. Nature, 2013, 494(7438): 459-462

8. Smith P, Martino D, Cai Z, Gwary D, Janzen H, Kumar P, McCarl B, Ogle S, O'Mara F, Rice C, Scholes B, Sirotenko O, Howden M, McAllister T, Pan G, Romanenkov V, Schneider U, Towprayoon S, Wattenbach M, SmithJ. Greenhouse gas mitigation in agriculture. Philosophical Transactions, 2008, 363(1492): 789-813

9. Chen X P, Cui Z L, Vitousek P M, Cassman K G, Matson P A, Bai J S, Meng Q F, Hou P, Yue S C, Römheld V, Zhang F S. Integrated soil-crop system management for food security. Proceedings of the National Academy of Sciences of the United States of America, 2011, 108(16): 6399-6404

10. Fan M, Shen J, Yuan L, Jiang R, Chen X, Davies W J, Zhang F. Improving crop productivity and resource use efficiency to ensure food security and environmental quality in China. Journal of Experimental Botany, 2012, 63(1): 13-24

11. Le C, Zha Y, Li Y, Sun D, Lu H, Yin B. Eutrophication of lake waters in China: cost, causes, and control. Environmental Management, 2010, 45(4): 662-668

12. Zheng X, Han S, Huang Y, Wang Y, Wang M. Re-quantifying the emission factors based on field measurements and estimating the direct $\mathrm{N}_{2} \mathrm{O}$ emission from Chinese croplands. Global Biogeochemical Cycles, 2004, 18(2): GB2018

13. FAO. FAOSTAT Database. Rome: agriculture production. Food and Agriculture Organization of the United Nations. http://www.fao.org/ home/en/, 2014-03-07

14. Cui Z, Chen X, Zhang F. Current nitrogen management status and measures to improve the intensive wheat-maize system in China. Ambio, 2010, 39(5-6): 376-384

15. Peng S B, Huang J L, Zhong X H. Research strategy in improving fertilizer-nitrogen use efficiency of irrigated rice in China. Scientia Agricultura Sinica, 2002, 35: 1095-1103 (In Chinese)

16. Zhao R F, Chen X P, Zhang F S, Zhang H, Schroder J, Roemheld V. Fertilization and nitrogen balance in a wheat-maize rotation system in North China. Agronomy Journal, 2006, 98(4): 938-945

17. Dobermann A, Witt C, Dawe D, Abdulrachman S, Gines H C, Nagarajan R, Satawathananont S, Son T T, Tan P S, Wang G H, Chien N V, Thoa V T K, Phung C V, Stalin P, Muthukrishnan P, Ravi V, Babu M, Chatuporn S, Sookthongsa J, Sun Q, Fu R, Simbahan G, Adviento M A A. Site-specific nutrient management for intensive rice cropping systems in Asia. Field Crops Research, 2002, 74(1): 37-66

18. Liu X, Ju X, Zhang F, Pan J, Christie P. Nitrogen dynamics and budgets in a winter wheat-maize cropping system in the North China Plain. Field Crops Research, 2003, 83(2): 111-124

19. Cui Z L, Chen X P, Miao Y X, Zhang F S, Sun Q P, Schroder J, Zhang H L, Li J L, Shi L W, Xu J F, Ye Y L, Liu C S, Yang Z P, Zhang Q, Huang S M, Bao D J. On-farm evaluation of the improved soil $\mathrm{N}_{\text {min }}$-based nitrogen management for summer maize in North China Plain. Agronomy Journal, 2008, 100(3): 517-525

20. Cui Z L, Zhang F S, Chen X P, Miao Y X, Li J L, Shi L W, Xu J F,
Ye Y L, Liu C S, Yang Z P, Qiang Z, Huang S M, Bao D J. On-farm evaluation of an in-season nitrogen management strategy based on soil $\mathrm{N}_{\min }$ test. Field Crops Research, 2008, 105(1-2): 48-55

21. Cui Z L, Chen X P, Zhang F S. Development of regional nitrogen rate guidelines for intensive cropping systems in China. Agronomy Journal, 2013, 105(5): 1411-1416

22. Zhu Z L. The status, problems and countermeasures of nitrogen fertilizer application in China. In: Li Q K, Zhu Z L, Yu T R, eds. Fertilizer issues of sustainable agriculture development in China. Nanjing: Jiangsu Science and Technology Press, 1998

23. Zhang F S, Wang J Q, Zhang W F, Cui Z L, Ma W Q, Chen X P. Nutrient use efficiencies of major cereal crops in China and measures for improvement. Acta Pedologica Sinica, 2008, 45: 915924 (In Chinese)

24. Dobermann A. Nutrient use efficiency-measurement and management. In: IFA International Workshop on Fertilizer Best Management Practices. Paris: International Fertilizer Industry Association, 2007

25. Raun W R, Johnson G V. Improving nitrogen use efficiency for cereal production. Agronomy Journal, 1999, 91(3): 357-363

26. Chinese Ministry of Environmental Protection. http://www.gov.cn/ jrzg/2010-02/10/content_1532174.htm, http://www.fao.org/home/ en/, 2014-03-07

27. Liu X J, Ju X T, Zhang Y, He C, Kopsch J, Zhang F S. Nitrogen deposition in agroecosystems in the Beijing area. Agriculture, Ecosystems \& Environment, 2006, 113(1-4): 370-377

28. He C E, Liu X, Fangmeier A, Zhang F. Quantifying the total airborne nitrogen input into agroecosystems in the North China Plain. Agriculture, Ecosystems \& Environment, 2007, 121(4): 395400

29. Shen J L, Tang A H, Liu X J, Fangmeier A, Goulding K T W, Zhang F S. High concentrations and dry deposition of reactive nitrogen species at two sites in the North China Plain. Environmental Pollution, 2009, 157(11): 3106-3113

30. Zhang Y, Liu X J, Fangmeier A, Goulding K T W, Zhang F S. Nitrogen inputs and isotopes in precipitation in the North China Plain. Atmospheric Environment, 2008, 42(7): 1436-1448

31. Goulding K W T, Bailey N J, Bradbury N J, Hargreaves P, Howe M, Murphy D V, Poulton P R, Willison T W. Nitrogen deposition and its contribution to nitrogen cycling and associated soil processes. New Phytologist, 1998, 139(1): 49-58

32. Fahey T J, Williams C J, Rooney-Varga J N, Cleveland C C, Postek K M, Smith S, Bouldin D R. DBouldin D R. Nitrogen deposition in and around an intensive agricultural district in central New York. Journal of Environmental Quality, 1999, 28(5): 1585-1600

33. Zhang W F, Dou Z X, He P, Ju X T, Powlson D, Chadwick D, Norse D, Lu Y L, Zhang Y, Wu L, Chen X P, Cassman K G, Zhang F S. New technologies reduce greenhouse gas emissions from nitrogenous fertilizer in China. Proceedings of the National Academy of Sciences of the United States of America, 2013, 110(21): 83758380

34. Cassman K G. Ecological intensification of cereal production systems: yield potential, soil quality, and precision agriculture. Proceedings of the National Academy of Sciences of the United States of America, 1999, 96(11): 5952-5959

35. Swaminathan M S. An evergreen revolution. Biologist, 2000, 47(2): 
85-89

36. Keating B A, Carberry P S, Bindraban P S, Asseng S, Meinke H, Dixon J. Eco-efficient agriculture: concepts, challenges, and opportunities. Crop Science, 2010, 50(Supplement 1): S-109-S-119

37. Carberry P S, Liang W L, Twomlow S, Holzworth D P, Dimes J P, McClelland T, Huth N I, Chen F, Hochman Z, Keating B A. Scope for improved eco-efficiency varies among diverse cropping systems. Proceedings of the National Academy of Sciences of the United States of America, 2013, 110(21): 8381-8386

38. Drinkwater L E, Snapp S S. Nutrients in agroecosystems: rethinking the management paradigm. Advances in Agronomy, 2007, 92: 163186

39. Ju X T, Christie P. Calculation of theoretical nitrogen rate for simple nitrogen recommendations in intensive cropping systems: a case study on the North China Plain. Field Crops Research, 2011, 124(3): 450-458

40. Robertson G P, Vitousek P M. Nitrogen in agriculture: balancing the cost of an essential resource. Annual Review of Environment and Resources, 2009, 34(1): 97-125

41. Vitousek P M, Naylor R, Crews T, David M B, Drinkwater L E, Holland E, Johnes P J, Katzenberger J, Martinelli L A, Matson P A, Nziguheba G, Ojima D, Palm C A, Robertson G P, Sanchez P A, Townsend A R, Zhang F S. Agriculture. Nutrient imbalances in agricultural development. Science, 2009, 324(5934): 1519-1520

42. Chen X, Zhang F, Romheld V, Horlacher D, Schulz R, BoningZilkens M, Wang P, Claupein W. Synchronizing N supply from soil and fertilizer and $\mathrm{N}$ demand of winter wheat by an improved $\mathrm{N}_{\text {min }}$ method. Nutrient Cycling in Agroecosystems, 2006, 74(2): 91-98

43. Li H, Huang G, Meng Q, Ma L, Yuan L, Wang F, Zhang W, Cui Z, Shen J, Chen X, Jiang R, Zhang F. Integrated soil and plant phosphorus management for crop and environment in China. A review. Plant and Soil, 2011, 349(1-2): 157-167

44. Wang X, Cao Y, Zhang F S, Chen X P. Application of building-up and maintenance approach in agriculture. Plant Nutrition and Fertilizer Science, 1995, 1: 59-63 (in Chinese)

45. Zhang F S, Cui Z L, Chen X P, Ju X T, Shen J B, Chen Q, Liu X J, Zhang W F, Mi G H, Fan M S, Jiang R F. Integrated nutrient management for food security and environmental quality in china. Advances in Agronomy, 2012, 116: 1-40

46. Cassman K G, Dobermann A, Walters D T. Agroecosystems, nitrogen-use efficiency, and nitrogen management. Ambio, 2002, 31 (2): $132-140$

47. Dobermann A, Cassman K G. Cereal area and nitrogen use efficiency are drivers of future nitrogen fertilizer consumption. Science in China. Series C: Life Sciences, 2005, 48: 745-758

48. Ju X T, Xing G X, Chen X P, Zhang S L, Zhang L J, Liu X J, Cui Z L, Yin B, Christie P, Zhu Z L, Zhang F S. Reducing environmental risk by improving $\mathrm{N}$ management in intensive Chinese agricultural systems. Proceedings of the National Academy of Sciences of the
United States of America, 2009, 106(9): 3041-3046

49. Cui Z L, Chen X P, Miao Y X, Li F, Zhang F S, Li J L, Ye Y L, Yang Z P, Zhang Q, Liu C S. On-farm evaluation of winter wheat yield response to residual soil nitrate-N in North China Plain. Agronomy Journal, 2008, 100(6): 1527-1534

50. Cui Z L, Zhang F S, Miao Y X, Sun Q P, Li F, Chen X P, Li J L, Ye Y L, Yang Z P, Zhang Q, Liu C S. Soil nitrate-N levels required for high yield maize production in the North China Plain. Nutrient Cycling in Agroecosystems, 2008, 82(2): 187-196

51. Ju X T, Liu X J, Zhang F S, Roelcke M. Nitrogen fertilization, soil nitrate accumulation, and policy recommendations in several agricultural regions of China. Ambio, 2004, 33(6): 300-305

52. Ju X T, Kou C L, Zhang F S, Christie P. Nitrogen balance and groundwater nitrate contamination: comparison among three intensive cropping systems on the North China Plain. Environmental Pollution, 2006, 143(1): 117-125

53. Cassman K G, Dobermann A, Walters D T, Yang H. Meeting cereal demand while protecting natural resources and improving environmental quality. Annual Review of Environment and Resources, 2003, 28(1): 315-358

54. Lobell D B, Cassman K G, Field C B. Crop yield gaps: their importance, magnitudes, and causes. Annual Review of Environment and Resources, 2009, 34(1): 179-204

55. Barning R. Economic evaluation of nitrogen application in the North China Plain. Dissertation for the Doctoral Degree. Stuttgart: Hohenheim University, 2008

56. Huang J K, Hu R F, Cao J M, Rozelle S. Training programs and inthe-field guidance to reduce China's overuse of fertilizer without hurting profitability. Journal of Soil and Water Conservation, 2008, 63(5): 165A-167A

57. Shen J B, Cui Z L, Miao Y X, Mi G, Zhang H Y, Fan M S, Zhang C C, Jiang R F, Zhang W F, Li H G, Chen X P, Li X L, Zhang F S. Transforming agriculture in China: from solely high yield to both high yield and high resource use efficiency. Global Food Security, 2013, 2(1): 1-8

58. Cui Z L, Dou Z X, Chen X P, Ju X T, Zhang F S. Managing agricultural nutrients for food security in china: past, present, and future. Agronomy Journal, 2013, 106(1): 191-198

59. Cui Z L, Yue S C, Wang G L, Meng Q F, Wu L, Yang Z P, Zhang Q, Li S Q, Zhang F S, Chen X P. Closing the yield gap could reduce projected greenhouse gas emissions: a case study of maize production in China. Global Change Biology, 2013, 19(8): 24672477

60. Zhang F S, Chen X P, Vitousek P. Chinese agriculture: an experiment for the world. Nature, 2013, 497(7447): 33-35

61. Matson P A, Naylor R, Ortiz-Monasterio I. Integration of environmental, agronomic, and economic aspects of fertilizer management. Science, 1998, 280(5360): 112-115 